\title{
The Perceived Treatment of Employees from DESIGNATED Groups IN THE WORKPLACE
}

\author{
Mariette Coetzee \\ Department of Human Resource Management, University of South Africa
}

Accepted: August 2014

\begin{abstract}
This article reports on employees' perceptions of the treatment of employees from designated groups in the workplace. The objective of the study was to identify the components of workplace treatment that indicate the perceived treatment of employees from designated groups. The study further investigated the influence of demographic factors on these perceptions.

A quantitative approach was followed, and a questionnaire was developed to collect data pertaining to employees' biographical details and their perceptions of the treatment of employees from designated groups in the workplace. The population consisted of 29688 employees at a leading South African bank and a sample of 1720 was used. A disproportionate, stratified sampling method was adopted and a sample of 349 employees participated. Factor analysis, correlations, $T$-tests and analysis of variance statistics were computed to achieve the objectives.

The factor analysis identified four factors relating to the treatment of employees from designated groups: task autonomy, respect, responsibility and realistic expectations. The results of the $T$-tests revealed that race, years of service and staff category do influence employees' perceptions of the treatment of workers from designated groups in terms of task autonomy and respect. Black respondents, unlike white respondents, believe that employees from designated groups are not treated with respect, nor are they accorded task autonomy.

This study represents a vital step towards a better understanding of the dimensionality of perceptions of fair and just treatment and should ultimately contribute to more effective treatment of all employees in the workplace.
\end{abstract}

Key words: affirmative action, employment equity, interactional justice, organisational citizenship behaviours, workplace treatment, task autonomy, respect, responsibility, realistic expectations

JEL: M540

1

\section{Introduction}

South Africa, no longer a pariah, has had preferred nation status across the world since the dawn of its democracy in 1994. The collapse of the apartheid systems made way for the new government to promulgate a series of Acts that sought to build a humane, inclusive, non-racial and caring society. These Acts include: the Labour Relations Act 66 of 1995 (focusing on employer-employee relations); the Basic Conditions of Employment Act 75 of 1998 (focusing on working conditions); the Employment Equity Act 55 of 1998 (focusing on the abolition of unfair discrimination; and the implementation of affirmative action measures in the workplace); and the Skills
Development Act 98 of 1998 (focusing on the training and development of the workforce).

This article relates more specifically to the Employment Equity (EE) Act 55 of 1998, particularly Chapter 3, which deals with affirmative action (AA). Although there is some evidence of success in the implementation of the EE Act, as reported year on year by the Employment Equity Commission (EEC), there is still more to be done in transforming the workplace in South Africa. The 2012/13 Employment Equity Report indicates that there has been reasonable improvement in the representation of designated groups in terms of transformation for the professionally qualified category of the workforce for the period 2002 to 2012. However, much remains to be done if such progress is to filter through to the top and 
senior management levels, particularly in the private sector of the economy. South Africa has made substantial progress towards meeting employment equity targets, as is illustrated in Figure 1. According to the population and employment statistics, the employment of blacks in the public sector needs to increase by only one per cent in order to be representative of the population (Census statistics, 2011). Despite this situation, AA has still not achieved equality in the workplace. In this context, equality refers not only to numbers, but also to employees from designated groups being empowered to play an active role in the success of the organisation. According to Harris (2009), the effectiveness and potential of AA may have yet to be realised. One possible explanation for why AA programmes are not achieving equality at work can be ascribed to the manner in which AA is implemented and more specifically to the treatment of employees from designated groups in the workplace.

Figure 1

Population and employment according to race
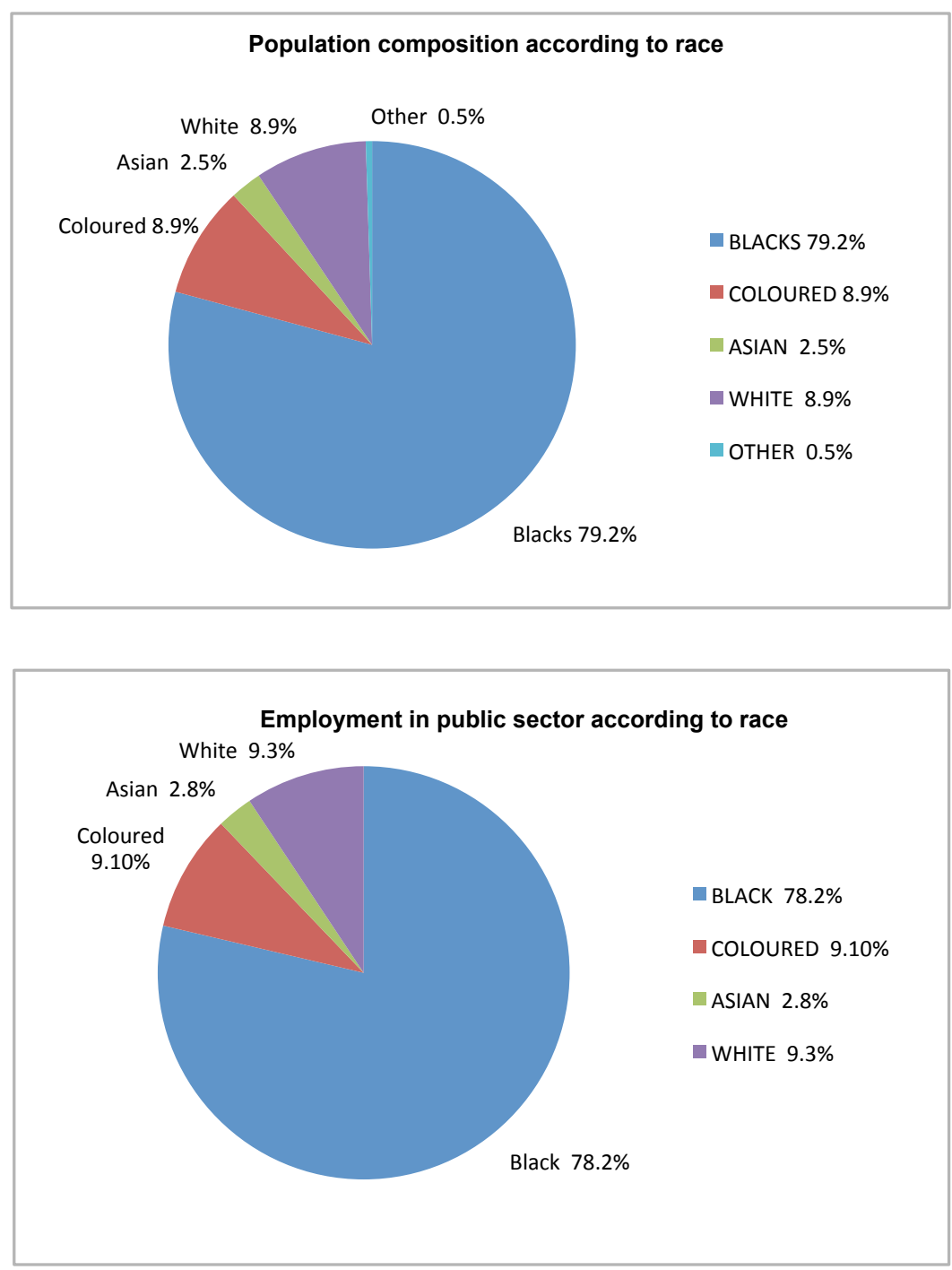

Source: Census statistics (2011) 
It is a fact well-established that the treatment of employees is of critical importance to the success of an organisation. Numerous studies have investigated the effect of their treatment in the workplace on employees' citizenship behaviour (Chiaburu \& Lim, 2008), job satisfaction, commitment (Johnson, Selenta \& Lord, 2006) and workplace civility (Sayers, Sears, Kelly \& Harbke, 2011). The way in which employees are treated also affects their psychological and emotional well-being, as well as their willingness to contribute to the goals of the organisation (Thau, Troster, Aquino, Pillutla \& De Cremer, 2013).

\subsection{Background}

For some decades now, AA measures have been the topic of passionate debate in many countries. These have instigated doubts about its legitimacy, and the effects of quotas and preferential treatment have been seen as reverse discrimination. In South Africa, AA is a mechanism for the redress of the injustices of apartheid. The question of discrimination was originally addressed in the definition of an unfair labour practice and was later discussed in greater detail with the promulgation of the Employment Equity Act 55 of 1998, which has the following two main aims: (1) promoting equal opportunities and fair treatment in employment through the elimination of unfair discrimination; and (2) implementing AA measures to redress the disadvantages in employment experienced by designated groups. Chapter 3 of the Employment Equity Act deals exclusively with AA. It obliges every designated employer to put in place measures for ensuring that suitably qualified persons from designated groups are afforded equal employment opportunities and are equitably represented in all occupational categories and levels of the workforce. These measures include eliminating barriers, furthering diversity, making reasonable accommodation for persons from designated groups, training and establishing numerical targets, but excluding the establishment of an absolute barrier to the prospective or continued employment of persons who are not from designated groups. The designated groups include the disabled, women and blacks. The term "blacks" is used as a generic term that includes all coloureds, Asians and Africans
(Bendix, 2010). In this study, the focus was on employees from designated groups.

Two of the most persistent questions asked about AA are whether or not the policy has been an effective remedy for inequities in employment for the groups it was intended to protect, and whether AA does, in fact, 'level the playing field' for these groups. In a study by Harris (2009), the results showed that, without AA, the employment status of employees from designated groups would have been worse. However, Harris confirms that the progress thus far is being offset by unfair practices like discrimination in pay, gender and treatment in the workplace. Because discrimination has become more subtle and difficult to identify and correct, many employees continue to endure unfair and unlawful discrimination in the workplace. Most women continue to work in jobs stereotyped as female jobs, receiving less pay, facing limits on promotion and having to endure sexual harassment (www.workplacefairness.org/sc/discrimination.php).

According to a study carried out in Britain by Fevre, Lewis, Robinson and Jones (2012), employees with disabilities, men, younger employees and lesbian, gay and bisexual employees are all more likely to experience illtreatment at work. Members of staff in associate professional and technical occupations, better paid employees and trade union members are also more likely to experience unreasonable treatment. However, according to the above study, the perpetrators of incivility and disrespect tended to be white men between the ages of 16 and 35 , in possession of a degree, responsible for managerial tasks and placed among the higher earners (Fevre et al., 2012). It is interesting to note that there was little reference to race, but, should the same study be conducted in South Africa, the results would probably reveal a different picture. Examples of unreasonable treatment include violence, humiliation, belittling, disrespect, offensive remarks and unmanageable workloads. These are exacerbated by employers following procedures improperly, micro management, opinions and input being ignored, and discriminatory treatment.

The examples of unreasonable treatment show clearly that individuals' relationships with their managers play a significant role in 
the way the treatment of employees is perceived. High-quality treatment by a manager signals that a staff member has status and is held in high esteem in the workplace (Thau et al., 2013). Fair treatment is of particular significance according to the findings of various studies, which have confirmed that workplace treatment has far-reaching consequences for both employees and the organisation when it comes to the following: civility (Pearson, Andersson \& Porath, 2005); job satisfaction (Hasan, 2010); organisational citizenship behaviours (Rego \& Cunha, 2010); quality of work life (Moghimi, Kazemi \& Samiie, 2012); turnover (Muzumdar, 2011); work behaviours (Le Roy, Bastounis \& Minibas-Poussard, 2012); interpersonal and organisational deviance (Berry, Ones \& Sackett, 2007); and workplace aggression (Hershcovis, Turner, Barling, Inness, LeBlanc, Arnold et al., 2007).

The concept of workplace treatment is closely related to interactional justice. According to Bies and Moag (1986), interactional justice denotes individuals' concerns about the quality of the interpersonal treatment they receive during the enactment of organisational procedures. The authors identified four attributes of interpersonally fair procedures: truthfulness; respect; propriety of questions; and justification. The sociologist John R. Schermerhorn defined interactional justice as the degree to which people are treated with dignity and respect. Interactional justice comprises interpersonal and informational justice. Interpersonal justice deals with dignity and respect, whereas informational justice deals with communication and showcases transparency. This would mean that employees' opinions, knowledge and experience should be used and acknowledged, so that they feel important and appreciated (Muzumdar, 2011).

Because interactional justice refers to the way employees are treated, it should be clear that managers play a crucial role in representing a larger organisation. In essence, treatment by a manager is of particular significance because it has a direct relationship with the quality of work life, organisational commitment and the extent to which employees are prepared to engage in organisational citizenship behaviours (OCBs). OCB is defined as those organisationally beneficial behaviours and gestures that can be neither enforced on the basis of formal role obligations nor elicited by contractual guarantees (Organ, 1990). According to social exchange theory (Blau, 1964), individuals respond to favourable treatment by organisations by offering in exchange something within their discretion. One way of reciprocating is by engaging in OCBs. Different forms of OCB have been identified and grouped into the following seven common themes: helping behaviour, sportsmanship, organisational loyalty, organisational compliance, individual initiative, civic virtue and self-development (Podsakoff, MacKenzie, Paine \& Bachrach, 2000). However, managers may enhance employees' perceptions of fairness by engaging in behaviours like consistency, integrity, proper communication, showing concern, treating employees with respect and courtesy and giving timely feedback (Burton \& Hoobler, 2011; Colquitt, Scott, Judge \& Shaw, 2006).

Ethics, quality of work life (QWL) and job satisfaction are increasingly being identified as indicators relating to the function and sustainability of organisations. QWL programmes attempt to address almost every aspect of an employee's working life. The term "quality of work life" originated in the concept of an open sociotechnical system designed to ensure autonomy in work, interdependence and selfinvolvement, with the idea of the best fit between technology and the social needs of employees (Moghimi et al., 2012). According to a study on the best 100 companies to work for in the USA, pride in work, autonomy, fairness and friendliness were listed as the top six criteria for rating organisations. These criteria are closely related to employees' values and confirm the findings of $\mathrm{Li}$ and Yeo (2011) that the quality of work life involves the satisfaction of needs at the following four levels: (1) work environment; (2) job requirements; (3) supervisory behaviour; and (4) ancillary programmes.

\subsection{Problem statement}

In implementing AA, it is inevitable that organisations will face the challenge of managing a diverse workforce. Racial equality appears to be the predominant issue in South Africa (Shen, Chanda, D’Netto \& Monga, 
2009). However, if AA and, thus, diversity are managed from a strategic and people-centred point of view, racial issues should not dictate how employees ought to be treated. They should always be treated with digniity as human beings, irrespective of race, gender, age or any other characteristic that makes them unique. According to Shen et al. (2009), little has changed in HRM diversity practices. Organisations find it difficult to facilitate change in culture and prejudices based on race and gender. Because it is easier to manage difficult issues like compliance with employment equity targets, the majority of organisations neglect to appreciate the challenges of managing a diverse workforce. Despite a strong business case for diversity management, there has been limited progress in moving towards equality at work for women in professional and managerial positions. Flexible work practices are often implemented in an undifferentiated manner that supports a traditional male work environment, and not enough is done to support working mothers in coping with family responsibilities (Johnston \& Teicher, 2010).

Although the way in which people are treated is important to everyone, the weight of that importance may vary systematically across different groups. Employees in designated groups in particular may be affected more by perceptions of treatment and interactional justice (Henry, 2011).

Various studies have been conducted to investigate the impact of interactional justice on organisational outcomes, such as retention and job satisfaction (Muzumdar, 2011). Job satisfaction has a significant emotional or evaluative component, and, while respectful treatment predicts job satisfaction for people generally (Colquitt, Conlon, Wesson, Porter \& $\mathrm{Ng}$, 2001), as far as respectful treatment communicates information about social inclusion, it is likely to be specifically valued by employees from designated groups (Henry, 2011).

One of the most difficult challenges of diversity management concerns the treatment of employees, each with his or her unique needs, goals, experiences and personal characteristics. In this regard, the specific interest of this study was to determine what employees from designated groups deemed important in their treatment.

\subsection{Research objectives}

The primary objective of this study was to determine how employees believe those from designated groups are treated in the workplace. A secondary objective was to determine the extent to which personal characteristics such as race, gender, years of service and staff category influence perceptions of the treatment of employees from designated groups.

\section{2}

\section{Research design}

\subsection{Research approach}

This study adopted a quantitative approach and a questionnaire was developed for collecting data on employees' biographical details and perceptions of how they believe employees from designated groups are treated in the workplace. Because of the paucity of research on the perceived treatment of employees from designated groups, a complete set of questions had to be developed in respect of the treatment of such employees.

\subsection{Research method}

\section{Population and sampling}

The population consisted of 29688 employees at a leading South African bank and a sample of 1720 was used.

A disproportionate, stratified sampling method was followed. The population was separated into subgroups referred to as "strata", and a sample was drawn randomly from each stratum. In this study, the subgroups were determined according to race, gender and staff category. When it came to race, employees from population groups other than white (blacks, coloureds and Asians) were treated as a single component of race. Regarding staff category, employees from top management, middle management and the supervisory level were treated as a single component. Once this process had been completed, a list of employees was drawn from each group. Table 1 provides a representation of the grouping of employees, the population and sample size of each employee group and the response and response rate. 
Table 1

Population, sample and response rate of each group

\begin{tabular}{|c|c|c|c|c|c|}
\hline & \multicolumn{2}{|c|}{ Population } & \multirow{2}{*}{$\begin{array}{r}\text { Sample } \\
688 \\
1032\end{array}$} & \multirow{2}{*}{$\begin{array}{c}\text { Response } \\
\\
128 \\
221\end{array}$} & \multirow{2}{*}{$\begin{array}{c}\text { Response rate } \\
\qquad \begin{array}{c}18.6 \% \\
21.4 \%\end{array}\end{array}$} \\
\hline $\begin{array}{l}\text { Blacks } \\
\text { Whites }\end{array}$ & $\begin{array}{l}12007(40 \%) \\
17681(60 \%)\end{array}$ & $100 \%$ & & & \\
\hline $\begin{array}{l}\text { GENDER } \\
\text { Men } \\
\text { Women }\end{array}$ & $\begin{array}{l}10088(34 \%) \\
19600(66 \%)\end{array}$ & $100 \%$ & $\begin{array}{r}585 \\
1135\end{array}$ & $\begin{array}{l}120 \\
229\end{array}$ & $\begin{array}{l}20.5 \% \\
20.2 \%\end{array}$ \\
\hline $\begin{array}{l}\text { STAFF CATEGORY } \\
\text { Top management } \\
\text { Middle management } \\
\text { Supervisory level }\end{array}$ & $\begin{array}{rl} & 253 \\
5 & 975(29 \%) \\
2502\end{array}$ & \multirow{3}{*}{$100 \%$} & 498 & 168 & $33.7 \%$ \\
\hline Clerical staff & $20958(71 \%)$ & & 1222 & 181 & $14.8 \%$ \\
\hline TOTAL & 29688 & & 1720 & 349 & $20.3 \%$ \\
\hline
\end{tabular}

According to various statisticians, an important consideration for a low response rate $(10$ per cent) for mail questionnaires is that the representivity of the population in the response is of greater significance than the general response percentage (Aaker, Kumar \& Day, 1995; Saunders, Lewis \& Thornhill, 2009). This principle is especially significant when a stratified sampling method is used. The response is in line with the composition of the sample. The response rate of 20 per cent in this study was therefore satisfactory.

\section{Measuring instrument}

The purpose of this study was to identify components of employee treatment that were specifically applicable to the treatment of employees from designated groups. A completely new questionnaire, comprising the following two sections, was developed: biographical details (13 items) and perceptions of fair treatment (26 items). The study made use of a six-point Likert-type scale, with anchors ranging from $1=$ "do not agree at all" to $6=$ "agree to a great extent" in respect of the section on perceptions of the treatment of employees from designated groups. The items were determined by referring to the literature on diversity management, workplace behaviour and fairness principles. Further inputs for the development of the questionnaire were obtained from the human resource manager of the bank, human resource experts, trade union officials and employees from different ethnic and gender groups. The assistance of a statistician was also obtained before the questionnaire was finalised.

\section{Research procedure}

The human resource manager of the bank provided a list of personnel, categorised according to race, gender and job category. The size of the sample was determined by the extent to which important cross-classifications had to be made. According to Welman and Kruger (2001), the size of the sample should be proportionate to $\sqrt{ } \mathrm{N}$, with $\mathrm{N}$ representing the size of the stratum. As the bank had a workforce of 29688 employees, a sample size of 770 would have been required. A total of 1 720 questionnaires was distributed to make provision for the possibility of a poor response rate. A total of 349 employees completed and returned the questionnaire, which provided a 20 per cent response rate. A list of all the permanent employees, categorised according to race, gender and job category, was obtained from the human resource manager at the bank and questionnaires were posted to the employees. Each completed questionnaire received was edited, and responses that could distort the data were discarded. The questions were coded and the SPSS Program for Windows Statistical Package, Release 11 and 12.5, was then employed to generate diagnostic information.

The bank provided ethical clearance for the study and the human resource manager of the bank authorised the questionnaire to ensure that the questions complied with ethical requirements.

\section{Statistical analysis}

A number of statistical techniques were used for analysing the data. The statistics used for 
nominal data included the mode, frequencies and coefficients of associations. The statistics used for interval data included factor analysis, correlations, $T$-test statistics (for two groups) and one-way analysis of variance (for more than two groups).

Factor analysis was used in this study. Principal components analysis (PCA) was conducted on the data using varimax rotation. PCA was also used to extract the number of factors that could account for the common variance (correlation) of a set of variables. This approach does not consider unique variances. The focus is on generating the most interpretable results with low probability of random error. Eigenvalue units were used to determine the strength of items that should remain in each factor. The eigenvalue for a given factor indicates the variance in all the variables of that factor. For the purposes of this study, all the factors with eigenvalues lower than one were ignored. As indicated in Table 2 , the sampling adequacy and sphericity tests displayed satisfactory results.

Varimax rotation was used because it yields results that facilitate the identification of each variable with a single factor. The name of the factor was determined by the items with the highest factor loadings. This study considered factor loadings higher than or equal to .40 as significant. Whenever an item showed a high loading on two or more factors, the researcher decided to which factor the item should belong. In order to determine which variables to retain, the researcher considered the factor loadings, the cross-loading of items on more than one factor and the reliability and importance of a variable according to the theory. Table 3 indicates the factors for the perceived treatment of employees from designated groups.

The Cronbach alpha coefficient and interitem correlation coefficients were used to assess the internal consistency of the measuring instruments. The Cronbach alpha coefficient was above .70 for all the factors identified, thereby indicating that all the items measured the same attribute. The widely-accepted social science cutoff is that alpha should be 0.70 or higher, which means that the standard error of measurement will be over half a standard deviation (Morgan \& Griego, 1998).
Descriptive statistics (e.g. means, standard deviations, skewness and kurtosis) were used to analyse the distribution of the values of each item included in the different factors.

Two types of statistics, namely parametric and nonparametric, are available when deciding on the most appropriate statistical method. A parametric test is appropriate when the population score is normally distributed, the variances of the groups are equal and the dependent variable is an interval scale. In order to determine whether a factor is normally distributed, the skewness and kurtosis should not be more than 2.5 times the standard error of skewness and kurtosis (Saunders et al., 2009). Table 4 provides the descriptive statistics and the results of the reliability analysis.

Pearson product-moment correlations were calculated to determine the direction and strength of the relationships between the variables. To avoid a Type 1 error, the significance value was set at a 95 per cent confidence level $(p \leq .05)$. The practical significance levels were set at a cut-off point of $d \geq .50$ (medium effect).

Comparative statistics test for differences between groups by making use of $T$-tests when an independent variable has two categories and a continuous dependent.

Analysis of variance (ANOVA) was used to test for significant mean differences between a single interval dependent and one independent variable with three or more categories.

\section{3}

\section{Results}

\subsection{Principal components analysis (PCA)}

As indicated in Table 2, the Kaiser-MeyerOlkin (KMO) test for measuring sampling adequacy and Bartlett's test of sphericity indicated satisfactory results. The KMO value (0.933) was greater than 0.7 , which means the data set was likely to factor well. Bartlett's test rejects the hypothesis (at $p<0.001$ ) that the correlation matrix is an identity matrix, without significant correlations between variables. Both diagnostic tests confirmed that the data were suitable for factor analysis. The 
eigenvalues of the four factors were all greater than 1.0, which is a common criterion if a factor is to be useful. The scree plot also supported a four factor solution.

Table 2

KMO measure and Bartlett's test: Employee treatment

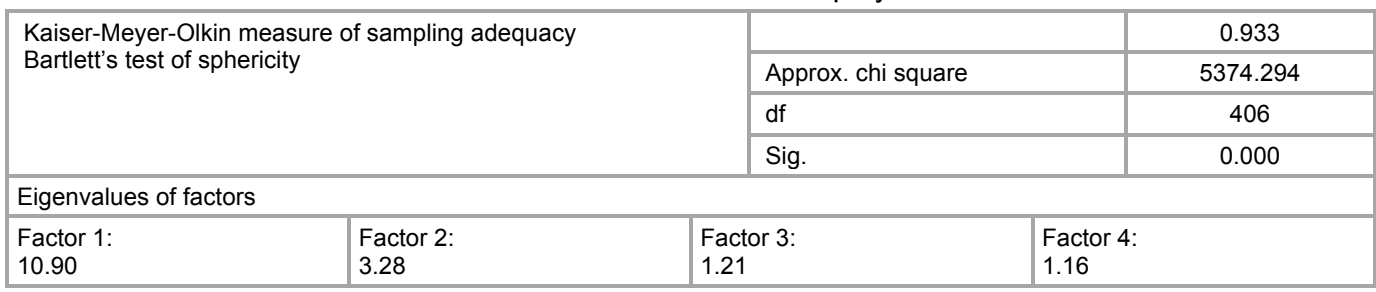

Table 3 indicates the rotated factor matrix for the treatment of employees from designated groups. Four factors in respect of employee treatment were identified.

Table 3

Rotated factor matrix for employee treatment

\begin{tabular}{|c|c|c|c|c|}
\hline & \\
\hline & Factor 1 & Factor 2 & Factor 3 & Factor 4 \\
\hline $\begin{array}{l}\text { Factor 1: Task autonomy } \\
\text { Significant and important jobs }\end{array}$ & 0.646 & & & \\
\hline Opportunity to use initiative or judgement & 0.627 & & & \\
\hline Challenging jobs & 0.623 & & & \\
\hline Variety of skills and competencies & 0.616 & & & \\
\hline Jobs that provide feedback on performance & 0.591 & & & \\
\hline Jobs that require cooperation with others & 0.579 & & & \\
\hline Jobs with clearly defined tasks & 0.577 & & & \\
\hline Determine their own work pace, order of tasks & 0.494 & & & \\
\hline $\begin{array}{l}\text { Factor 2: Respect } \\
\text { Treated with respect and dignity }\end{array}$ & & 0.868 & & \\
\hline Listened to when they make suggestions & & 0.676 & & \\
\hline Free to discuss problems with co-workers & & 0.653 & & \\
\hline Recognised for work done well & & 0.575 & & \\
\hline $\begin{array}{l}\text { Employees from designated groups are seen as contributors } \\
\text { to success }\end{array}$ & & 0.573 & & \\
\hline Social events consider cultural differences & & 0.463 & & \\
\hline $\begin{array}{l}\text { Factor 3: Responsibility } \\
\text { Responsible for assignments and projects }\end{array}$ & & & 0.861 & \\
\hline Responsible for equipment and facilities & & & 0.719 & \\
\hline Responsible for initiating assignments and projects & & & 0.664 & \\
\hline Responsible for budgets and expenditures & & & 0.595 & \\
\hline $\begin{array}{l}\text { Factor 4: Realistic expectations } \\
\text { Expected to meet realistic performance standards }\end{array}$ & & & & 0.721 \\
\hline Expected to meet realistic workloads & & & & 0.583 \\
\hline Held accountable for their decisions & & & & 0.567 \\
\hline Personally responsible for work performed & & & & 0.558 \\
\hline
\end{tabular}

\section{Factor 1: Task autonomy}

This factor refers to the level of autonomy employees from designated groups have in the workplace. The elements of this factor include the following: the significance, importance and difficulty of jobs performed by employees from designated groups; their opportunity of using their initiative and judgement; the extent 
to which the job allows them to use a variety of skills and competencies; whether they receive feedback on performance; the level of cooperation required to perform a task; the extent to which tasks are defined; and whether employees are allowed to determine their own work pace and the order in which tasks have to be completed.

\section{Factor 2: Respect}

This factor refers to the way in which employees from designated groups are treated in the workplace, and in particular how they are treated as human beings. According to this factor, employees from designated groups feel that they are treated with respect when they are treated with dignity, people listen to them when they make suggestions; they feel free to discuss problems with co-workers; they are recognised for work well done; they are regarded as contributing to the success of the department; and their cultural differences are taken into consideration at social events.

\section{Factor 3: Responsibility}

This factor refers to the responsibility with which employees from designated groups wish to be entrusted. Employees from designated groups want to accept responsibility for important tasks, such as specific assignments and projects, equipment and facilities, initiating assignments and projects, and budgets and expenditures.

\section{Factor 4: Realistic expectations}

This factor refers to the way in which employees from designated groups expect to be treated regarding their expectations. It indicates that employees from designated groups should be expected to meet realistic performance standards and workloads. In addition, they expect to be held accountable for their decisions and the work they perform.

\subsection{Descriptive statistics}

Table 4 provides the means, standard deviations, skewness, kurtosis and internal consistency reliability coefficients and intercorrelations for the treatment of employees from designated groups. The results show that the reliability of the factors, as measured by alpha, are all above .70, which confirms the internal consistency of the items in a factor. In order to determine whether a factor is normally distributed, the skewness and kurtosis should not be more than 2.5 times the standard error of skewness and kurtosis. In this instance, the skewness of a factor should be less than .32 and the kurtosis should be less than .65 to be regarded as normally distributed

Table 4

Descriptive statistics and reliability analysis in respect of employee treatment

\begin{tabular}{|l|l|l|l|l|l|c|c|c|}
\hline $\begin{array}{c}\text { Treatment } \\
\text { factors }\end{array}$ & Mean & Variance & $\begin{array}{c}\text { Std. } \\
\text { deviation }\end{array}$ & Skewness & Kurtosis & $\begin{array}{c}\text { No. of } \\
\text { participants }\end{array}$ & $\begin{array}{c}\text { No. of } \\
\text { items }\end{array}$ & $\begin{array}{c}\text { Cronbach } \\
\text { alpha }\end{array}$ \\
\hline Task autonomy & 32.04 & 59.49 & 7.71 & -.24 & -.10 & 349 & 8 & .91 \\
\hline Respect & 24.68 & 47.29 & 6.88 & -.51 & -.36 & 349 & 6 & .90 \\
\hline Responsibility & 14.18 & 20.99 & 4.58 & .04 & -.42 & 349 & 4 & .87 \\
\hline Realistic expectations & 16.81 & 16.99 & 4.12 & -.21 & -.66 & 349 & 6 & .86 \\
\hline
\end{tabular}

\subsection{T-tests and analysis of variance}

Table 4 provides an analysis of the relationship between employee demographic characteristics and the treatment of employees from designated groups. Table 4 indicates how the various groups (race, years of service at the bank and staff category) differ regarding perceptions of the treatment of employees from designated groups in the workplace. As the dependent variables were approximately normally distributed and measured on a scale that at least approximates interval data, parametric $T$-tests were used. The SPSS program provided applicable statistics where Levens' $F$-test was significant and the assumption of normality was violated. The main findings include the following:

Gender, marital status and number of years in current position

No significant differences in the perceived treatment of employees from designated groups in the workplace could be found for gender, marital status or the number of years' service in a current position. 
Race

According to Table 5, there are statistically significant differences $(p<0.001)$ between blacks' and whites' perceptions of how employees from designated groups are treated in the workplace. The differences between blacks and whites are of practical significance when it comes to task autonomy $(d=0.60)$ and respect $(d=0.54)$. Blacks, unlike whites, believe that they receive little autonomy $\left(\sum=\right.$ 28.962) and respect $\left(\sum=22.118\right)$.

Years of service at the bank

Table 5 indicates that there are significant differences $(p<0.05)$ between employees with seven or more years of service and employees with fewer than seven years of service. There are statistically significant differences between these two groups of employees regarding task autonomy $(p=0.004)$ and respect $(p=0.001)$. However, the practical significance of these differences is small $(d<0.50)$, and one can therefore conclude that the number of years' service has only a minor effect on the perceptions of the treatment of employees from designated groups in the workplace. According to the mean scores, although these are not conclusive, employees with more than seven years of service $\left(\sum=33.041\right)$ seem to believe that employees from designated groups do receive task autonomy $\left(\sum=33.205\right)$ and are treated with respect $\left(\sum=25.849\right)$ in the workplace. Since there is a significant association (eta $=0.498$ ) between years of service at the bank and race, it is possible that race rather than the number of years of service determines perceptions of the treatment of employees from designated groups.

\section{Staff category}

According to Table 5, there are significant differences $(p<0.05)$ between management and clerical staff in respect of task autonomy $(p=0.005)$ and respect $(p=0.004)$. In contrast with the opinion of clerical staff, management believes that employees from designated groups are given task autonomy $\left(\sum=33.233\right)$ and are treated with respect $\left(\sum=25.757\right)$.

Table 5

Students' t-test: comparison of mean scores of race, number of years' service and staff category in respect of employee treatment

\begin{tabular}{|c|c|c|c|c|c|c|c|c|c|c|}
\hline & & \multirow[t]{2}{*}{$N$} & \multirow[t]{2}{*}{ Mean } & \multirow[t]{2}{*}{$\begin{array}{c}\text { Std. } \\
\text { deviation }\end{array}$} & \multicolumn{2}{|c|}{$\begin{array}{l}\text { Levene's test } \\
\text { for equality of } \\
\text { variances }\end{array}$} & \multirow[t]{2}{*}{$t$} & \multirow[t]{2}{*}{ df } & \multirow{2}{*}{$\begin{array}{l}\text { Sig. (2- } \\
\text { tailed) } \\
\quad p\end{array}$} & \multirow{2}{*}{$\begin{array}{c}\text { Practical } \\
\text { significance } \\
d\end{array}$} \\
\hline & & & & & $\mathbf{F}$ & Sig. & & & & \\
\hline \multicolumn{11}{|l|}{ RACE } \\
\hline \multirow[t]{2}{*}{ AUTONOMY } & Black & 128 & 28.96 & 8.09 & 3.28 & 0.071 & -5.96 & 347 & 0.000 & 0.60 \\
\hline & White & 221 & 33.83 & 6.95 & & & -5.74 & 235.72 & 0.000 & \\
\hline \multirow[t]{2}{*}{ RESPECT } & Black & 128 & 22.12 & 7.44 & 11.64 & $0.001^{*}$ & -5.52 & 347 & 0.000 & \\
\hline & White & 221 & 26.17 & 6.07 & & & -5.23 & 224.42 & 0.000 & 0.54 \\
\hline \multirow[t]{2}{*}{ RESPONSIBILITY } & Black & 128 & 13.46 & 4.51 & 0.38 & 0.538 & -2.27 & 347 & 0.024 & 0.25 \\
\hline & White & 221 & 14.61 & 4.58 & & & -2.28 & 269.05 & 0.023 & \\
\hline \multirow[t]{2}{*}{ EXPECTATIONS } & Black & 128 & 16.05 & 4.34 & 2.94 & 0.087 & -2.66 & 347 & 0.008 & 0.28 \\
\hline & White & 221 & 17.26 & 3.93 & & & -2.59 & 244.41 & 0.010 & \\
\hline \multicolumn{11}{|c|}{ NUMBER OF YEARS' SERVICE } \\
\hline \multirow[t]{2}{*}{ AUTONOMY } & $1-7$ years & 173 & 30.81 & 7.71 & 0.56 & 0.456 & -2.91 & 343 & 0.004 & 0.31 \\
\hline & $8-39$ years & 172 & 33.21 & 7.56 & & & -2.91 & 342.92 & 0.004 & \\
\hline \multirow[t]{2}{*}{ RESPECT } & $1-7$ years & 173 & 23.40 & 7.20 & 4.80 & $0.029^{*}$ & -3.35 & 343 & 0.001 & \\
\hline & $8-39$ years & 172 & 25.85 & 6.36 & & & -3.35 & 338.30 & 0.001 & 0.34 \\
\hline \multirow[t]{2}{*}{ RESPONSIBILITY } & $1-7$ years & 173 & 13.75 & 4.62 & 0.030 & 0.862 & -1.96 & 343 & 0.051 & \\
\hline & 8-39 years & 172 & 14.71 & 4.50 & & & -1.96 & 342.86 & 0.051 & \\
\hline \multirow[t]{2}{*}{ EXPECTATIONS } & $1-7$ years & 173 & 16.45 & 4.27 & 2.84 & 0.093 & -1.73 & 343 & 0.084 & \\
\hline & 8-39 years & 172 & 17.22 & 3.96 & & & -1.73 & 341.41 & 0.084 & \\
\hline
\end{tabular}




\begin{tabular}{|c|c|c|c|c|c|c|c|c|c|c|}
\hline \multicolumn{11}{|l|}{ STAFF CATEGORY } \\
\hline \multirow[t]{2}{*}{ AUTONOMY } & Management & 168 & 33.23 & 6.70 & \multirow[t]{2}{*}{9.76} & $0.002^{*}$ & 2.80 & 347 & 0.005 & \\
\hline & Clerical & 181 & 30.95 & 8.42 & & & 2.82 & 339.26 & 0.005 & 0.27 \\
\hline \multirow[t]{2}{*}{ RESPECT } & Management & 168 & 25.76 & 5.86 & \multirow[t]{2}{*}{18.24} & $0.000^{*}$ & 2.85 & 347 & 0.005 & \\
\hline & Clerical & 181 & 23.68 & 7.58 & & & 2.87 & 336.09 & 0.004 & 0.27 \\
\hline \multirow[t]{2}{*}{ RESPONSIBILITY } & Management & 168 & 14.65 & 4.27 & \multirow[t]{2}{*}{1.38} & 0.241 & 1.794 & 347 & 0.074 & \\
\hline & Clerical & 181 & 13.77 & 4.83 & & & 1.802 & 346.25 & 0.072 & \\
\hline \multirow[t]{2}{*}{ EXPECTATIONS } & Management & 168 & 16.79 & 4.00 & \multirow[t]{2}{*}{1.33} & \multirow[t]{2}{*}{0.250} & \multirow[t]{2}{*}{-0.108} & 347 & 0.914 & \\
\hline & Clerical & 181 & 16.84 & 4.25 & & & & 346.93 & 0.914 & \\
\hline
\end{tabular}

4

\section{Discussion}

\subsection{Outline of the results}

The objective of the study was to determine how employees perceive the treatment of employees from designated groups in the workplace. A further objective was to determine the extent to which demographic variables influence employees' perceptions of the treatment of those from designated groups in the workplace.

\subsection{Components of treatment in the workplace}

In this study a completely new questionnaire was used to identify the components of the treatment of employees from designated groups. Using factor analysis, the following four factors relating to the treatment of employees from designated groups were extracted: factor 1: task autonomy; factor 2: respect; factor 3 : responsibility; and factor 4 : realistic expectations. These factors relate to the quality of interaction and confirm the importance of the human aspect of organisational practices (Jafari, Shafiepour \& Yarmohammadian, 2011). Regarding task autonomy (factor 1), employees from designated groups wish to be given more than just tasks; they need to be given autonomy as well. Responsibility (factor 3) refers to the fact that AA employees wish to be given responsibility and held accountable for their actions. These results support the findings of the motivational theory on the job characteristics model. Task significance and autonomy are two central characteristics in the job characteristics model (Piccolo, Greenbaum, Den Hartog \& Folger, 2010). Job autonomy reflects the extent to which a job allows the freedom, independence or discretion to schedule work, make decisions or select the methods used to perform tasks (Hackman \& Oldham, 1976).

Respect (factor 2), a key aspect of any interpersonal relationship, emphasises the central role played by managers in employees' attitudes, self-esteem and behaviour (Ambrose, Schminke \& Mayer, 2013). Much has been said about the implementation of AA, but unless it is implemented in such a way that employees from designated groups are given a genuine opportunity to succeed, AA will never achieve its objectives.

Affording employees from designated groups the opportunity of succeeding involves having realistic expectations of their performance. Despite measures to level the playing field in the workplace, employees from designated groups are still in a disadvantaged position when it comes to work experience, opportunities afforded and cultural beliefs. Employees believe that realistic expectations of the abilities and performance of employees from designated groups will ultimately enable them to succeed.

\subsection{The influence of biographical factors on perceptions of the treatment of employees from designated groups}

Regarding employee characteristics, the research identified the following three biographical factors that influence employees' perceptions of the treatment of employees from designated groups in the workplace: race, number of years' service and staff category. Blacks, employees with fewer years' service and clerical staff believe that they receive little task autonomy and respect. Respectful treatment may be more consequential for members of designated groups because they are often 
excluded from society. Members of designated groups show a stronger relationship between respectful treatment and job satisfaction (Henry, 2011; Piccolo et al., 2010). Although feelings about respectful treatment are only perceptions, employees perceive them to be real, and managers should increase the perceived fairness of their interactions with these groups of employees.

This study indicated that treatment in the workplace in terms of task autonomy, respect, responsibility and expectations is directly related to interactional fairness and outlined how employees from designated groups wish to be treated in the workplace.

\section{5}

\section{Limitations of the study}

Overall, the results suggest that the measures of treatment of employees from designated groups are sufficiently reliable and valid to capture the kind of treatment deemed the most important for the treatment of employees from designated groups. However, elements that influence employees' perceptions of the treatment of employees from designated groups may depend on various personal, situational and organisational factors, corroborating Greenberg's (1987) concerns about the contextual sensitivity of behaviour and attitudes. Not limiting the sample to a single organisation could have resolved some of the problems relating to contextual sensitivity.

The treatment behaviours that were investigated represent a subset of the many types of behaviours found in organisations. Perceptions are informed by reality as well as personal values and beliefs - hence the need for future research to explore contextual moderators in understanding employees' perceptions of the treatment of employees from designated groups in more depth.
6

\section{Conclusion}

This study identified four categories of treatment employees regarded as important when it comes to the treatment of employees from designated groups, namely task autonomy, respect, responsibility and realistic expectations. When managers fail to provide employees from designated groups with task autonomy, treat them with respect, give them responsibilities and have realistic expectations of their performance, employees experience interactional injustice. This tends to impact negatively on the overall performance of the organisation because it may have to cope with employees who are not valued or efficiently utilised. This study supported previous research findings that interpersonal justice exists when managers engage in ethical leadership, treat all employees with respect and dignity and demonstrate valuing the employees' contributions by allowing them task autonomy and responsibilities (Piccolo et al., 2010). Closer inspection of the results and consideration of the basic principles of interactional justice, job autonomy, respect, responsibility and realistic expectations are important to all employees and not only to employees from designated groups.

Organisations are social systems in which human resources are the principal factor that ensures effectiveness and efficiency. Organisations need effective managers and employees if they are to achieve their objectives. Employee job performance and satisfaction are key variables that impact on organisations' performance. It is thus managers' task to identify factors that might threaten the performance and satisfaction of employees. One such factor is interactional justice, which involves the quality of the interpersonal treatment of employees.

\section{References}

AAKER, D.A., KUMAR, V. \& DAY, G.S. 1995. Marketing research (5th ed.) New York: Wiley. AMBROSE, M.L., SCHMINKE, M. \& MAYER, D.M. 2013. Trickle-down effects of supervisor perceptions of interactional justice: A moderated mediation approach. Journal of Applied Psychology. DOI: 10.1037/ a0032080 [accessed 2013-09-16].

BERRY, C.M., ONES, D.S. \& SACKETT, P.R. 2007. Interpersonal deviance, organizational deviance, and their common correlates: A review and meta-analysis. Journal of Applied Psychology, 92:410-424. 
BENDIX, S. 2010. Industrial relations in South Africa (5th ed.) Cape Town: Juta.

BIES, R.J. \& MOAG, J.S. 1986. Interactional justice: communication criteria for fairness. In B. Sheppard (ed.) Research on negotiation in organizations, 1:43-55.

BLAU, P.M. 1964. Exchange and power in social life. New York: Wiley.

BURTON, J.P. \& HOOBLER, J.M. 2011. Aggressive reactions to abusive supervision: The role of interactional justice and narcissism. Scandinavian Journal of Psychology, 52(4):389-398.

CHIABURU, D.S. \& LIM, A.S. 2008. Manager trustworthiness or interactional justice? Predicting organizational citizenship behaviors. Journal of Business Ethics, 83(3):453-467.

COLQUITT, J.A., CONLON, D.E., WESSON, M.J., PORTER, C.O.L.H. \& NG, K.Y. 2001. Justice at the millennium: A meta-analytic review of 25 years of organizational justice research. Journal of Applied Psychology, 86:425-445.

COLQUITT, J.A., SCOTT, B.A., JUDGE, T.A. \& SHAW, J.C. 2006. Justice and personality: Using integrative theories to derive moderators of justice effects. Organizational Behavior and Human Decision Processes, 100:110-127.

FEVRE, R., LEWIS, D., ROBINSON, A. \& JONES, T. 2012. Insight into ill-treatment in the workplace: Patterns, causes and solutions. Contemporary Readings in Law and Social Justice, 4(2):245-277.

GREENBERG, J. 1987. A taxonomy of organisational justice theories. Academy of Management Review, 12 : 9-22.

HACKMAN, J.R. \& OLDHAM, G.R. 1976. Motivation through the design of work: Test of a theory. Organizational Behavior and Human Performance, 16:250-279.

HARRIS, G.L.A. 2009. Revisiting affirmative action in levelling the playing field: Who have been the true beneficiaries anyway? Review of Public Personnel Administration, 29(4):354-372.

HASAN, A.A. 2010. A study of relationship between organizational justice and job satisfaction. International Journal of Business and Management, 5(12):102-109.

HENRY, P. 2011. The role of group-based status in job satisfaction: Workplace respect matters more for the stigmatized. Social Justice Research, 24(3):231-238.

HERSHCOVIS, M.S., TURNER, N., BARLING, J., INNESS, M., LEBLANC, M.M., ARNOLD, K.A. et al., 2007. Predicting workplace aggression: A meta-analysis. Journal of Applied Psychology, 92:228-238.

JAFARI, P., SHAFIEPOUR M.F. \& YARMOHAMMADIAN, M.H. 2011. Designing an adjusted model of organizational justice for an educational system in Esfahan City (Iran). Procedia Social and Behavioral Sciences, 15:1696-1704.

JOHNSON, R.E., SELENTA, C. \& LORD, R.G. 2006. When organizational justice and the self-concept meet: Consequences for the organization and its members. Organizational Behavior and Human Decision Processes, 99:175-01.

JOHNSTON, S. \& TEICHER, J. 2010. Is diversity management past its "use-by-date" for professional and managerial women? International Journal of Employment Studies, 18(1): 34-62.

KATZ, D. 1964. The motivational basis of organisational behaviour. Behavioural Science, 9:131-133.

LE ROY, J. BASTOUNIS, M. \& MINIBAS-POUSSARD, J. 2012. Interactional justice and counterproductive work behaviours: The mediating role of negative emotions. Social Behavior \& Personality: An International Journal, 40(8):1341-1355.

LI, J. \& YEO, R.K. 2011. Quality of work life and career development: Perceptions of part-time MBA students. Employee Relations, 33(3):201-220.

MOGHIMI, S.M., KAZEMI, M. \& SAMIIE, S. 2012. Studying the relationship between organisational justice and employees' quality of work life in public organizations: A case study of Qom Province. Iranian Journal of Management Studies, 6(1):119-145.

MORGAN, AG \& GRIEGO, OV. 1998. Easy use and interpretation of SPSS for Windows: Answering research questions with statistics. London: Lawrence Erlbaum Associates.

MUZUMDAR, P. 2011. Influence of interactional justice on the turnover behavioral decision in an organisation. Journal of Behavioral Studies in Business, 4:1-11.

ORGAN, D.W. 1990. The motivational basis of organizational citizenship behavior. Research in Organizational Behavior, $12: 43-72$. 
PEARSON, C.M., ANDERSSON, L.M. \& PORATH, C.L. 2005. Workplace incivility. In S. Fox \& P.E. Spector (eds.) Counterproductive work behavior: Investigations of actors and targets (pp. 177-200). Washington, DC: American Psychological Association.

PICCOLO, R.E., GREENBAUM, R., DEN HARTOG, D.N. \& FOLGER, R. 2010. The relationship between ethnical leadership and core job characteristics. Journal of Organizational Behavior, 31:259-278.

PODSAKOFF, P.M., MACKENZIE, S.B., PAINE, J.B. \& BACHRACH, D.G. 2000. Organisational citizenship behaviours: A critical review of the theoretical en empirical literature and suggestions for future research. Journal of Management, 26(3):513-563.

REGO, A. \& CUNHA, M.P. 2010. Organisational justice and citizenship behaviors: A study in the Portuguese cultural context. Applied Psychology: An International Review, 59(3):404-430.

SAUNDERS, M.N.K., LEWIS, P. \& THORNHILL, A. 2009. Research methods for business students (5th ed.) London: Pitman.

SAYERS, J.K., SEARS, K.L., KELLY, K.M. \& HARBKE, C.R. 2011. When employees engage in workplace incivility: The interactive effect of psychological contract violation and organizational justice. Journal of Employ Response Rights, 23:269-283.

SHEN, J., CHANDA, A., D’NETTO, B. \& MONGA, M. 2009. Managing diversity through human resource management: An international perspective and conceptual framework. International Journal of Human Resource Management, 20(2):235-251.

THAU, S., TROSTER, C., AQUINO, K., PILlUTLA, M. \& DE CREMER, D. 2013. Satisfying individual desires or moral standards? Preferential treatment and group members" self-worth, affect, and behaviour. Journal of Business Ethics, 113(1):133-145.

WELMAN, J.C. \& KRUGER, S.J. 2001. Research methodology for the business and administrative sciences. Oxford: Oxford University Press.

\section{Internet sites}

www.workplacefairness.org/sc/discrimination.php

CENSUS STATISTICS. 2011. Available at: http://www.statssa.gov.za/publications/p03014/p030142011.pdf [accessed 2014-10-15]. 